Additional Perspectives articles for Influenza: The Cutting Edge book collection are available at http://perspectivesinmedicine.cshlp.org/cgi/collection/influenza_the_cutting_edge.

\title{
H5 Influenza Viruses in Egypt
}

\author{
Rabeh El-Shesheny, ${ }^{1,2}$ Ahmed Kandeil, ${ }^{2}$ Ahmed Mostafa, ${ }^{2}$ Mohamed A. Ali, ${ }^{2}$ \\ and Richard J. Webby ${ }^{1}$ \\ ${ }^{1}$ Department of Infectious Diseases, St. Jude Children's Research Hospital, Memphis, Tennessee \\ 38105-3678, USA \\ ${ }^{2}$ Center of Scientific Excellence for Influenza Viruses, National Research Centre, Giza 12622, Egypt \\ Correspondence: richard.webby@stjude.org
}

For almost a decade, Egypt has been endemic for highly pathogenic avian influenza (HPAI) $\mathrm{A}(\mathrm{H} 5 \mathrm{~N} 1)$ viruses. In addition to being catastrophic for poultry production, $\mathrm{A}(\mathrm{H} 5 \mathrm{~N} 1)$ has also caused 359 human infections in the country ( 40\% of global cases), with 120 being fatal. From 2017, A(H5N1) viruses have been gradually replaced by HPAI A(H5N8) viruses seeded from Southeast Asia through Europe; no human cases have been reported since. This lack of human cases is not a consequence of fewer $\mathrm{H} 5$ infections in poultry. Despite governmental outbreak control, the number of avian influenza outbreaks has increased since 2006 partially fueled by noncompliance with preventive measures and suboptimal vaccination programs. Adherence to control measures is low because of social norms, especially among women and children - the main caretakers of household flocks in rural areas-and declining public awareness in the community. Egypt has thus become an epicenter for $\mathrm{A}(\mathrm{H} 5)$ virus evolution, with no clear resolution in sight.

W aterfowl and shorebirds are the major natural reservoirs for influenza A virus (IAV) (Webster et al. 1992). Historically, it was considered that within these reservoirs, IAV is maintained in the low pathogenic (LP) form, inducing only mild illness, if any. Following spillover to domestic gallinaceous poultry (including chicken and turkey), some viruses of H5 and H7 subtypes can transform to the highly pathogenic (HP) form and cause lethal infections (Alexander 2000) by altering the proteolytic cleavage site of the hemagglutinin (HA) protein and adjacent residues (Schmier et al. 2015). The high virulence of these HP viruses as well as their circulation within domestic species likely contributed to their relatively confined geographic distribution after their genera- tion. This pattern of confined geographic distribution changed with the emergence of the HP A/goose/Guangdong/1/96 lineage (Gs/GD) $\mathrm{A}(\mathrm{H} 5 \mathrm{~N} 1)$ viruses clade 2.2 viruses, designated based on HA gene sequence, from this lineage were initially causing disease confined to China and southeast Asia (Guan et al. 2004; Saad et al. 2007). They later spread westward, concomitant with their detection in wild migratory birds and seeded outbreaks in countries along the way. The clade 2.2 viruses were first detected in poultry in Egypt in mid-February 2006 (Saad et al. 2007). Although most countries wherein Gs/GD A(H5N1) viruses have been isolated have had transient epidemics, others have not been as successful in eradicating the viruses and they have become endemic. Egypt is one such

Editors: Gabriele Neumann and Yoshihiro Kawaoka

Additional Perspectives on Influenza: The Cutting Edge available at www.perspectivesinmedicine.org

Copyright (C) 2021 Cold Spring Harbor Laboratory Press; all rights reserved; doi: 10.1101/cshperspect.a038745

Cite this article as Cold Spring Harb Perspect Med 2021;11:a038745 
R. El-Shesheny et al.

country in which these viruses have become endemic.

Egypt is in the northeast corner of Africa, spanning $\sim 1$ million square kilometers. As per United Nations estimates, the human population of Egypt is 100 million, with most living in the Nile Delta or in the narrow Nile Valley located south of Cairo. Poultry production is one of the fastest growing industries in Egypt, and most birds are found in commercial or backyard farms. Commercial farms include large and small farms that account for $>75 \%$ of the total poultry production (Abdelwhab and Hafez 2011). Chickens are the most common bird raised, followed by ducks, geese, and turkeys. The backyard sector is critical for low-income households, and the cultural norm is for families in villages to raise mixed (e.g., chickens, pigeons, ducks, geese, and turkeys) backyard flocks for egg and meat consumption. The live poultry market (LPM) sector is also very active and plays a critical role in maintaining, amplifying, and disseminating avian influenza viruses (AIVs) among poultry species and from poultry to humans (Dinh et al. 2006; Zhou et al. 2009; Kandeel et al. 2010). Soon after their introduction, the clade 2.2 viruses were found in all major poultry sectors in Egypt.

The first human case of Gs/GD A(H5N1) in Egypt was detected in March 2006. Since then, Egypt has reported the highest number of human cases of H5 virus infections. As of September 2019, there have been 359 laboratory-confirmed human cases of H5N1 in Egypt reported to the World Health Organization (WHO), and the case fatality rate is $>33.5 \%$ (WHO 2019).

The epidemiology of AIVs in Egypt has been influenced by two other events, both subsequent to the $\mathrm{A}(\mathrm{H} 5 \mathrm{~N} 1)$ introduction in 2006. In the first event in 2011, A(H9N2) G1-lineage viruses similar to those detected in neighboring countries were detected in poultry in Egypt. The $\mathrm{A}(\mathrm{H} 9 \mathrm{~N} 2)$ viruses are now geographically widespread across the country, and co-infection with $\mathrm{A}(\mathrm{H} 5)$ viruses is common (El-Zoghby et al. 2012a; Kandeil et al. 2014; Kayali et al. 2014; Naguib et al. 2015). In the second event, there was another introduction(s) of Gs/GD A(H5) viruses from Asia, this time of clade 2.3.4.4
A(H5N8) viruses (Kandeil et al. 2017; Salaheldin et al. 2018a). These viruses have slowly displaced clade 2.2 viruses and have not been detected in humans, but reassortment with circulating $\mathrm{A}(\mathrm{H} 9 \mathrm{~N} 2)$ viruses has been observed (Hagag et al. 2019) (see below for more details).

In this review, we summarize the epidemiology and zoonotic characteristics of endemic $\mathrm{A}(\mathrm{H} 5)$ viruses circulating in Egypt and discuss some perceived weaknesses in response and control strategies that have contributed to their continued endemicity.

\section{CURRENT EPIDEMIOLOGY OF A(H5) IN EGYPT}

\section{Emergence and Epidemiology of $\mathrm{A}(\mathrm{H} 5 \mathrm{~N} 1)$ Viruses in Egypt}

The $\mathrm{A}(\mathrm{H} 5 \mathrm{~N} 1)$ virus was first detected in Egypt in the common teal (Anas crecca) in December 2005 during migratory bird sampling along the northern coastal region of the Damietta Governorate. Genetic analysis of this virus indicated a close relation to the A/bar-headed goose/Qinghai/65/2005 clade 2.2 virus detected months earlier during a large die-off of migratory birds in Qinghai Lake, China. Although definitive proof is lacking, the timing of events strongly suggests that wild bird migration led to transcontinental spread of the virus. Consistent with this hypothesis are the 34 stopover sites for migrating birds from the East Africa-West Asia and Black Sea-Mediterranean flyways present in Egypt (Fig. 1). After being identified in waterfowl, clade 2.2 viruses were isolated from poultry farms and backyard flocks in February 2006 across most governorates of Egypt. Control measures were implemented, including the culling of 40 million birds within a 10 -mo period, causing serious losses to the poultry sectors. However, these efforts were not successful, and the virus became endemic. Once endemic, poultry outbreaks of $\mathrm{A}(\mathrm{H} 5 \mathrm{~N} 1)$ influenza settled into a mostly seasonal pattern, with sharp increases in activity during the colder months (November-March). The highest numbers of outbreaks have been recorded in Dakahliya, Monofiya, Kalyobiya, Sharqeia, Gharbia, and Giza Governor- 


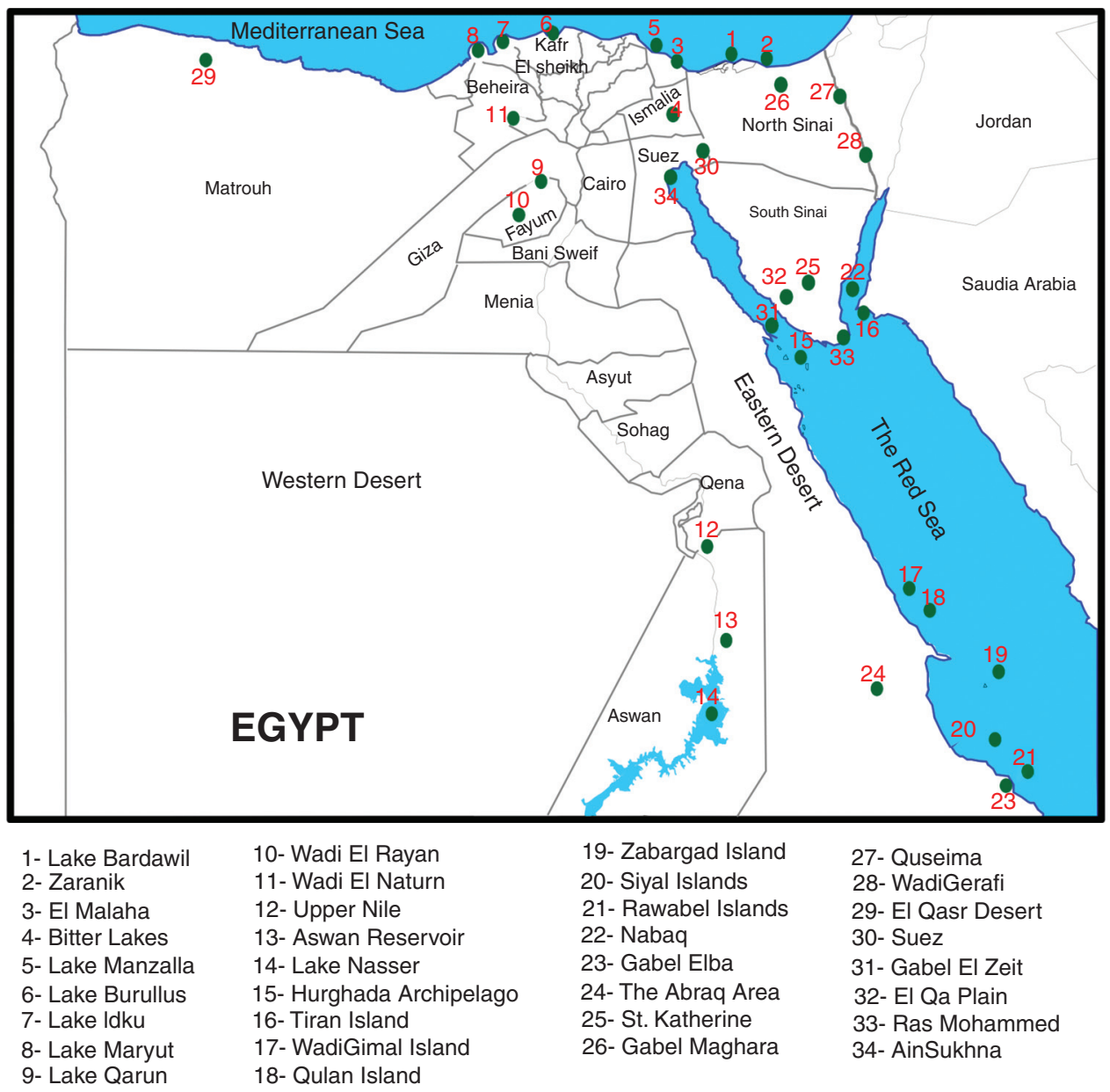

Figure 1. Locations of 34 wild bird stopover sites in Egypt.

ates, which are leading poultry-producing governorates in Egypt (Fig. 2A; El-Zoghby et al. 2013; Kayali et al. 2016; ElMasry et al. 2017; EMPRES 2019).

To better understand the ecology and evolution of viruses in Egypt, an active, longitudinal AIV surveillance program was implemented in 2009. Commercial and semicommercial farms, abattoirs, backyard flocks, and live bird markets (LBMs) were targeted across the country. The program had a $5 \%$ rate of AIV detection during 2009-2010, which was exclusively attributable to $\mathrm{A}(\mathrm{H} 5 \mathrm{~N} 1)$ infection, primarily in the commercial production sector (Kayali et al. 2011a). From 2010 to 2013, the detection rate increased to $10 \%$, with $\mathrm{A}(\mathrm{H} 5 \mathrm{~N} 1), \mathrm{A}(\mathrm{H} 9 \mathrm{~N} 2)$, and $\mathrm{H} 5 \mathrm{~N} 1 /$
H9N2 co-infections detected. Importantly, in addition to an increase in prevalence, viruses were also detected in all poultry production sectors (Kayali et al. 2014). The AIV detection rate decreased to $4.6 \%$ from 2013 to 2015 , and no $\mathrm{A}(\mathrm{H} 5 \mathrm{~N} 1)$ viruses were detected in the last quarter of 2015 (Kayed et al. 2016). Finally, from 2016 to 2018 , the detection rate was $2.9 \%$, with $\mathrm{A}(\mathrm{H} 9 \mathrm{~N} 2)$ being the most commonly isolated viruses; however, the $\mathrm{A}(\mathrm{H} 5)$ viruses have remained.

\section{Genetic Evolution of A(H5N1) Viruses in Egypt}

In the decade or more that $\mathrm{A}(\mathrm{H} 51)$ viruses have circulated in Egypt, they have predictably undergone substantial genetic evolution. As dis- 
R. El-Shesheny et al.
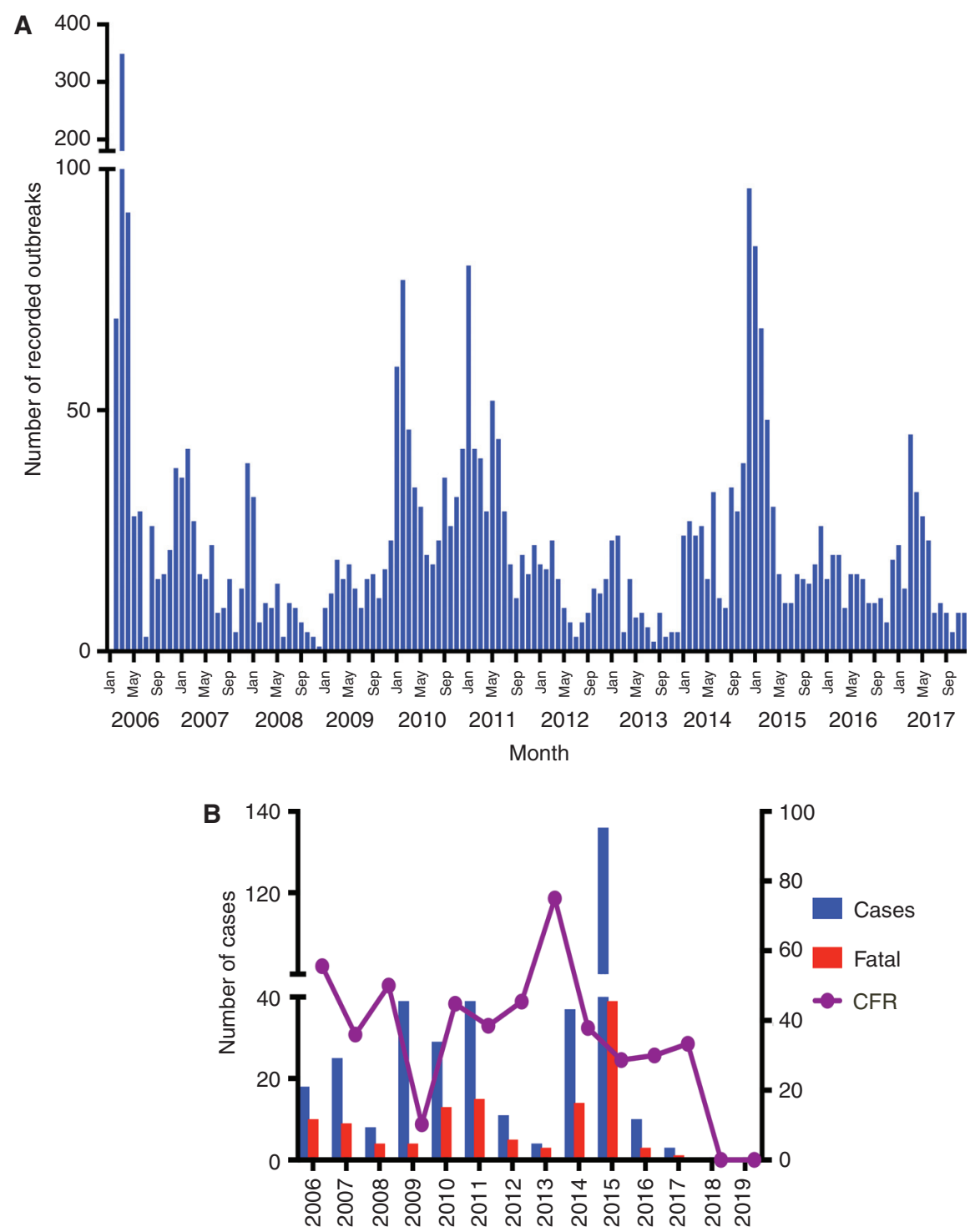

Figure 2. Epidemic curve for $(A)$ poultry and $(B)$ human cases of A(H5N1) in Egypt from 2006 to 2019.

cussed, the first $\mathrm{A}(\mathrm{H} 5 \mathrm{~N} 1)$ viruses to enter Egypt had HA genes belonging to phylogenetic clade 2.2. After a period of circulation, a review of the nomenclature subsequently identified an Egyptspecific subgroup within clade 2.2 , with a new 2.2.1 clade being proposed to cover it. The continued circulation of these clade 2.2.1 viruses in vaccinated (commercial sector) and nonvaccinated poultry sectors led to a within-country diversification of the viruses, likely through differential pressures of maintenance within flocks with distinct immunities. Clade 2.2.1 viruses within the commercial sector eventually evolved to a point where they met the criteria for independent clade status. Clade 2.2.1 viruses were subsequently subdivided into clades 2.2.1.1 and 2.2.1.1a (commercial sector) in response to this increased diversity. Both clades cocirculated for several years until the 2.2.1.1a viruses, for reasons unknown, disappeared around 2014. Subsequent drift of clade 2.2.1.1 viruses eventually prompted a 2.2.1.2 clade designation of vi- 


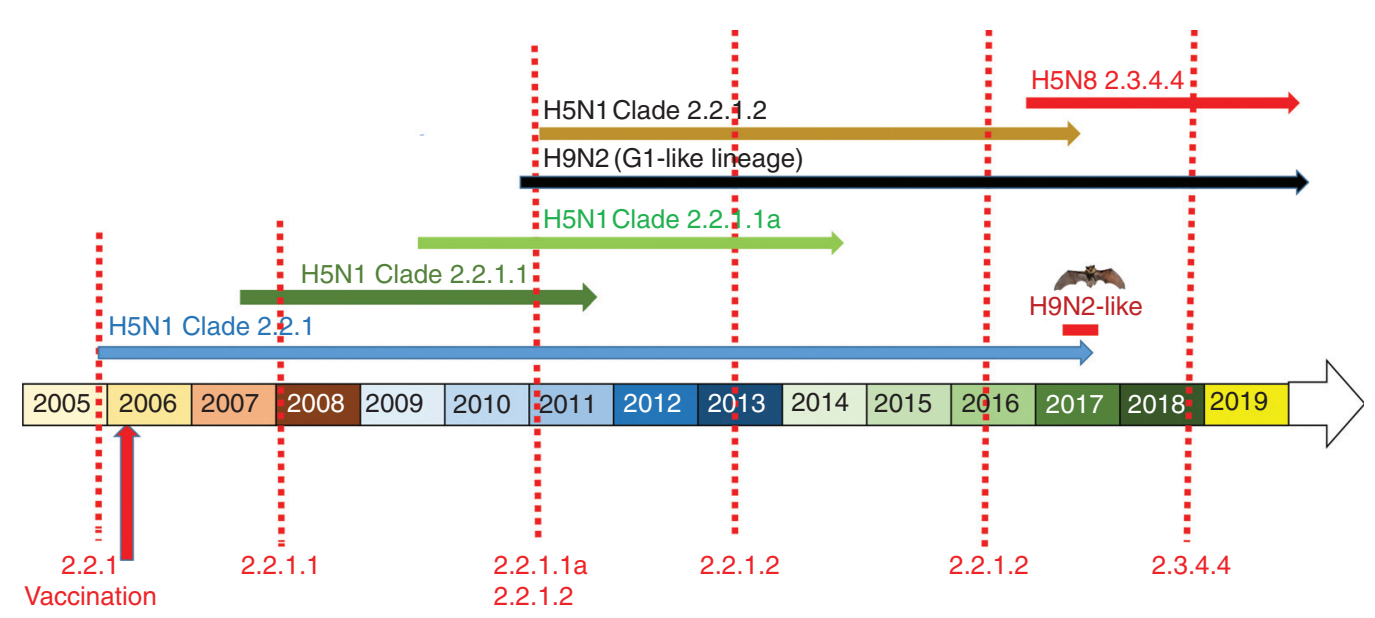

Figure 3. Timeline of the evolution of A(H5) clades of avian influenza in Egypt from 2005 to 2019.

ruses in the country (Fig. 3; Kayali et al. 2011b, 2016; Abdelwhab et al. 2012a, 2016; El-Shesheny et al. 2014; Arafa et al. 2015).

Evolution of the $\mathrm{H} 5$ gene of Egyptian viruses not only led to changes in their classification but also to noticeable antigenic changes (El-Shesheny et al. 2012; Kayali et al. 2016). Viruses drifted antigenically over time through glycosylation changes as well as mutations in key HA antigenic sites. El Shesheny et al. evaluated the antigenic cross-reactivity of HPAI H5N1 viruses from 2006 to 2017 by using a panel of antigenic site $\mathrm{A}$ and $\mathrm{B}$ reactive monoclonal antibodies raised against $\mathrm{HAs}$ of $\mathrm{A} / \mathrm{Viet} \mathrm{Nam} / 1203 / 04$ (H5N1; clade 1) and A/bar-headed goose/Qinghai lake/1A/05 (H5N1; clade 2.2). Viruses fell into three clusters: $\mathrm{A}, \mathrm{B}$, and $\mathrm{C}$. Cluster A included isolates from 2006 to 2007 (clade 2.2.1), cluster B included isolates from 2008 to 2010 (clade 2.2.1.1 and clade 2.2.1.1a), and cluster C included isolates from 2011 to 2012 (clade 2.2.1.2) (El-Shesheny et al. 2012). The alignment of genetic and antigenic clustering suggested that immune pressure may have driven virus evolution, as has been postulated for other $\mathrm{A}(\mathrm{H} 5 \mathrm{~N} 1)$ viruses (Cattoli et al. 2011). HA amino acid mutations $(74,140,141,144,156,162$, and 184) were observed in clade 2.2.1.1 viruses and were associated with antigenic drift and reduced vaccine effectiveness (Abdelwhab et al. 2012a; El-Shesheny et al. 2014). It has been suggested that the emergence of new antigenic var- iants can be partially explained by inadequate vaccines and vaccination policies driving drift rather than control.

The genetic evolution of $\mathrm{A}(\mathrm{H} 5 \mathrm{~N} 1)$ viruses in Egypt was also associated, somewhat concerningly, with phenotypic differences in virus receptor binding. Clade 2.2.1.2 viruses evolved an HA deletion at residue 129 and also amino acid substitutions D43N, S120N/D, and I151T, and these changes resulted in enhanced binding to the host cell receptor that is preferred by human influenza viruses (Kayali et al. 2011b; Watanabe et al. 2011; Abdelwhab et al. 2012a; El-Shesheny et al. 2014). Laboratory adaptation studies of earlier A(H5N1) viruses from Vietnam and Indonesia showed that a limited number of genetic changes are needed for airborne transmission among ferrets (Herfst et al. 2012; Imai et al. 2012). One of the identified HA mutations, T156A, resulted in loss of a potential glycosylation site and is also common to all viruses of clade 2.2.1.2. A mutation at PB2E627K was also required for efficient airborne transmissibility and was common in Egyptian $\mathrm{A}(\mathrm{H} 5 \mathrm{~N} 1)$ viruses isolated from infected poultry and humans. Additional studies have shown many HA substitutions, most present at some level in Egyptian $\mathrm{A}(\mathrm{H} 5 \mathrm{~N} 1)$ viruses, which can enhance binding to the human virus receptor (Chen et al. 2012; Schmier et al. 2015).

Anti-influenza drugs, including adamantanes (amantadine and rimantadine) and neur- 
R. El-Shesheny et al.

aminidase (NA) inhibitors (oseltamivir and zanamivir) are available for treating IAV infection. In Egypt, many human cases of A(H5N1) have been treated with oseltamivir. Resistance to oseltamivir through an NA N295S mutation was confirmed in two fatal cases within the same family (Earhart et al. 2009). Luckily, most Egyptian human and avian $\mathrm{A}(\mathrm{H} 5 \mathrm{~N} 1)$ viruses did not have NA inhibitor-associated resistance markers (Kayali et al. 2011b; El-Shesheny et al. 2014). In contrast, the amantadine resistance-associated S31N mutation was commonly observed in viruses belonging to clades 2.2.1.1 and 2.2.1.2 (El-Shesheny et al. 2016; Abdelwhab et al. 2017). The development of an M2 V27A substitution, which was also associated with amantadine resistance, was detected in two human 2.2.1.1 A(H5N1) isolates (Younan et al. 2013).

\section{Biological Properties of $\mathrm{A}(\mathrm{H} 5 \mathrm{~N} 1)$ Viruses in Egypt}

The $\mathrm{A}(\mathrm{H} 5 \mathrm{~N} 1)$ viruses have been isolated from a wide range of hosts in Egypt, including chickens, ducks, quails, pigeons, ostriches, great egrets, crews, donkeys, pigs, wild birds, and humans (Saad et al. 2007; Aly et al. 2008; Abdel-Moneim et al. 2010; Abdelwhab and Hafez 2011; Kayali et al. 2011a, 2016; El-Zoghby et al. 2012b; Kayed et al. 2019). This diverse range facilitates spread of the virus and can contribute to viral diversity. Despite this and an increase in the number of human cases, there have been limited studies evaluating the biological properties of Egyptian $\mathrm{A}(\mathrm{H} 5 \mathrm{~N} 1)$ viruses in mammalian models. Nine poultry viruses isolated between 2014 and 2015 from clade 2.2.1.2 were evaluated for their ability to transmit in ferrets (Arafa et al. 2016). As has been typical for $\mathrm{A}(\mathrm{H} 5 \mathrm{~N} 1)$ viruses from other regions, these viruses could not transmit efficiently among ferrets. Despite limited transmission of $\mathrm{A}(\mathrm{H} 5 \mathrm{~N} 1)$ viruses among ferrets (and among humans), zoonotic infections have occurred, many within LPMs, suggesting that unique conditions occur in these environments (Lai et al. 2016). Bertran et al. (2017) experimentally demonstrated that naive chickens and ferrets exposed to the same air space in which chickens were slaughtered became infect- ed and died. Consistent with these results, AIV has been detected and isolated from air samples in LPMs (Wu et al. 2018).

The pattern of $\mathrm{A}(\mathrm{H} 5 \mathrm{~N} 1)$ virus pathogenicity in poultry in Egypt changed from the first wave of 2006 viruses. The observed mortality increased (up to 100\%) in poultry flocks in 2006-2007 and then dropped to $20 \%-60 \%$ in 2008-2017 (Kayali et al. 2011b). These field observations were supported by laboratory data showing a range of intravenous pathogenicity indexes (1.8 to 2.9) for these viruses (Abdelwhab et al. 2016). Field observations showed that in contrast to chickens, ducks exhibit mild or no clinical signs after infection with $\mathrm{A}(\mathrm{H} 5 \mathrm{~N} 1)$ viruses. Pekin ducks experimentally infected with a clade 2.2.1.2 virus showed no clinical signs or mortality (Salaheldin et al. 2018b; Samir et al. 2018), suggesting a potential role for ducks in maintaining clade 2.2.1.2 viruses as the dominant virus in Egypt.

\section{Zoonotic Infections of $\mathrm{A}(\mathrm{H} 5 \mathrm{~N} 1)$ Viruses}

More than 860 zoonotic infections of $\mathrm{A}(\mathrm{H} 5 \mathrm{~N} 1)$ viruses have been reported in 16 countries, with a case fatality rate of $>50 \%$ (WHO 2019). Egypt accounts for a substantial proportion of these infections, with a current laboratory-confirmed case count of 359 and a case fatality rate of $33.5 \%$ (Fig. 2B). During the winter of 2014 2015 , there was a sharp increase in human cases of $\mathrm{A}(\mathrm{H} 5 \mathrm{~N} 1)$ associated with clade 2.1.2.2 viruses. Although startling, the reason for the rise in human cases is unclear, and since 2016 only 13 new cases have been reported. In the 11 years of $\mathrm{A}(\mathrm{H} 5 \mathrm{~N} 1)$ virus circulation in Egypt, human cases have been detected with clade 2.2.1 and 2.2.1.2 viruses, which were dominant in the backyard sector. Correspondingly, $70 \%$ of human cases have been from individuals who reported exposure to backyard poultry (Kayali et al. 2016). Although the number of human infections in Egypt has been relatively high, screening for $\mathrm{A}(\mathrm{H} 5)$ infection is based on a case definition of influenza-like illness and a history of poultry contact $2 \mathrm{wk}$ prior to disease onset (Refaey et al. 2015). It is very likely that the official case count is an underestimate, because 
many infected people might have milder symptoms. Such individuals are unlikely to seek medical care in Egypt. A 3-yr seroprevalence study found that $\sim 2 \%$ of Egyptians exposed to poultry showed evidence of prior $\mathrm{A}(\mathrm{H} 5 \mathrm{~N} 1)$ exposure (Gomaa et al. 2015). A further study conducted in the Beheira Governorate showed a $4 \%$ seroprevalence in poultry workers (Samaha et al. 2015). These studies confirm that the number of $\mathrm{A}(\mathrm{H} 5 \mathrm{~N} 1)$ human cases in Egypt is greatly underreported, and consequently the case fatality rate is greatly overestimated. Interestingly, there was an increase in the number of human cases reported in 2014-2015, when the Egyptian Ministry of Health actively collected additional respiratory samples in communities having poultry outbreaks (Kayali et al. 2016).

\section{EMERGENCE OF HPAIV H5N8}

For more than a decade, the majority of Gs/GD lineage $\mathrm{A}(\mathrm{H} 5)$ viruses had been associated with the N1 NA. However, in 2010, this trend changed with the detection and spread of $\mathrm{A}(\mathrm{H} 5 \mathrm{~N} 8)$ viruses in China. These viruses were initially reported in wild birds and poultry in Southeast Asia (primarily China). The association of these viruses with wild birds was likely a key factor in their subsequent dissemination to Korea and Japan and then to Siberia, Europe, and the United States (Harder et al. 2015; Lee et al. 2017). In 2016, there was another wave of $\mathrm{A}(\mathrm{H} 5 \mathrm{~N} 8)$ virus dissemination from Asia (Beerens et al. 2017; Fusaro et al. 2017; Kleyheeg et al. 2017; Pohlmann et al. 2017; Scoizec et al. 2018). In November 2016, these A (H5N8) viruses were detected in Egypt, likely introduced via Europe; these viruses are still present and represent the dominant $\mathrm{A}(\mathrm{H} 5)$ currently circulating (Fig. 3; Kandeil et al. 2017). The $\mathrm{A}(\mathrm{H} 5 \mathrm{~N} 8)$ virus situation has been further complicated by multiple introductions of $\mathrm{A}(\mathrm{H} 5 \mathrm{~N} 8)$ virus into Egypt (Yehia et al. 2018). Although it is premature to suggest their disappearance, as $\mathrm{A}(\mathrm{H} 5 \mathrm{~N} 8)$ virus detections have increased, $\mathrm{A}(\mathrm{H} 5 \mathrm{~N} 1)$ virus detections have dramatically decreased. As $\mathrm{A}(\mathrm{H} 5 \mathrm{~N} 8)$ viruses have not yet been associated with human infections, the displacement of $\mathrm{A}(\mathrm{H} 5 \mathrm{~N} 1)$ viruses with
$\mathrm{A}(\mathrm{H} 5 \mathrm{~N} 8)$ viruses may well be beneficial from a public health perspective.

\section{REASSORTMENT OF HPAIV H5Nx IN EGYPT}

Cocirculation of HPAI (H5N1, H5N8) and LPAI (H9N2) viruses in poultry provides an opportunity for reassortment. Co-infection of birds with $\mathrm{A}(\mathrm{H} 5)$ and $\mathrm{A}(\mathrm{H} 9 \mathrm{~N} 2)$ viruses in Egypt is not uncommon, yet few reassortments have been detected to date (Abdelwhab el et al. 2010; Kayali et al. 2016; Hassan et al. 2019). A(H5N1)/ $\mathrm{A}(\mathrm{H} 9 \mathrm{~N} 2)$ reassortants have been detected in other countries where these viruses cocirculate, suggesting that there is not complete incompatibility between their gene segments (Monne et al. 2013; Marinova-Petkova et al. 2016). Lack of detection of reassortant viruses in Egypt may also be due to lack of sensitivity of current surveillance measures for identifying such viruses or an associated fitness defect (Moatasim et al. 2017; Naguib et al. 2017; Arai et al. 2019). Although no $\mathrm{A}(\mathrm{H} 5 \mathrm{~N} 1) / \mathrm{A}(\mathrm{H} 9 \mathrm{~N} 2)$ reassortants have been described, a novel $\mathrm{A}(\mathrm{H} 5 \mathrm{~N} 8) / \mathrm{A}(\mathrm{H} 5 \mathrm{~N} 1)$ reassortant has been detected in a duck. This virus contained seven $\mathrm{A}(\mathrm{H} 5 \mathrm{~N} 8)$ virus genes with the $\mathrm{N} 2$ from the $\mathrm{A}(\mathrm{H} 9 \mathrm{~N} 2)$ virus (Hagag et al. 2019). The complete significance of this or similar viruses remains unknown.

\section{CHALLENGES IN CONTROLLING HPAIV H5N1 IN EGYPT}

In Egypt, thousands of $\mathrm{A}(\mathrm{H} 5)$ outbreaks have been recorded in poultry since February 2006 and have resulted in severe economic losses for the poultry industry. These losses have affected the incomes of 1.5 million people whose livelihoods depend on this industry. The first wave of the disease in 2006 resulted in the culling of 40 million birds in an attempt by the veterinary authority in Egypt to control the infection in commercial farms (Peyre et al. 2009). Further attempts at control have included elements of vaccination, ongoing active surveillance, rapid diagnosis, biosecurity enhancement, regular training, awareness programs for poultry workers, and further culling of infected poultry (Swayne 2012). 
R. El-Shesheny et al.

\section{Vaccination}

Much of the funds made available for AIV control in Egypt have been directed toward vaccination (Peyre et al. 2009). Vaccination of backyard and commercial poultry began with the first wave of viruses in 2006, and different types of inactivated $\mathrm{H} 5$ vaccines, mainly based on North American $\mathrm{H} 5 \mathrm{~N} 2$ viruses and reverse genetic modification of GD/GD viruses (H5N1,Re-1), were used (Hafez et al. 2010). More than a quarter of a billion doses of several commercial vaccines were imported by the Egyptian government. As discussed above, from 2007 to 2011 antigenic drift variants of $\mathrm{A}(\mathrm{H} 5 \mathrm{~N} 1)$ viruses were detected in vaccinated chicken (Balish et al. 2010). In July 2009, the government-supported vaccination of backyard poultry was terminated (Peyre et al. 2009). Ten years later, implementation of AI vaccination in Egypt has had a limited impact on the presence of the virus.

At least 24 commercial inactivated AI H5 vaccines have been licensed for use in poultry in Egypt as per General Organization of Veterinary Services files. These vaccines have contained a diverse range of antigens ranging from older H5 lineage viruses to several Gs/GD lineage viruses. Older $\mathrm{H} 5$ vaccine antigens include A/turkey/Minnesota/3689-1551/1981 (H5N2), A/chicken/Mexico/232/1994 (H5N2), A/duck/ Potsdam/1402/1986 (H5N2), A/chicken/Italy/ 22A/1998 (H5N9), A/turkey/England/N28/ 1973 (H5N2), and A/turkey/Wisconsin/1968 (H5N9). Reverse genetics-derived antigens include Re-1 (A/goose/Guangdong/1996 (H5N1) clade 0), A/chicken/VN/C58/2004 (H5N3) (clade 1), Re-5 (A/duck/Anhui/1/2006 (H5N1) clade 2.3.4), Re-6 (A/duck/Guangdong/S1322/ 2006 (H5N1) clade 2.3.2), Re-Egy (A/chicken/ Egypt/18-H/2008 (H5N1) clade 2.2.1.1), A/ chicken/Egypt/Q1995D/2010 (H5N1) clade 2.2.1.1, and A/chicken/Egypt/M2583D/2010 (H5N1) clade 2.2.1.2. These vaccine antigens represent a considerable amount of antigen space and have had variable homology to circulating viruses raging from limited to high. The HA homology of the most abundantly used vaccines to circulating Egyptian viruses (at the time of the study) had been estimated to range from
$78 \%$ to $94 \%$ (Abdelwhab and Hafez 2011). Efficacy studies on these commercial vaccines in poultry have shown incomplete protection (Kim et al. 2010; Kilany et al. 2011; Kayali et al. 2013). Continual reappraisal of the efficacy of available vaccines needs to become an integral component of response measures (Pfeiffer et al. 2010).

In addition to vaccine mismatch, the main factors contributing to vaccination failure in Egypt include the presence of maternal immunity during vaccination (Kim et al. 2010; Abdelwhab et al. 2012b), absence of intensive country-wide vaccination programs, age of birds during vaccination (Peyre et al. 2009), number of vaccination doses required for each type of poultry (Peyre et al. 2009), immunosuppression due to concurrent cryptosporidiosis (Eladl et al. 2014), inflammatory bowel disease live vaccines, mycotoxicosis (Abdelwhab et al. 2016), and reluctance to vaccinate breeder and backyard poultry. Clearly, vaccination must be an integral component of Egypt's continued control efforts, but several variables and confounders need to be fully evaluated to optimize the effects.

\section{Biosecurity}

Biosecurity is the first line of defense against infectious diseases. Several practices are needed to limit the introduction of infections into a poultry production unit. These practices are divided into three major categories: segregation, to keep contaminated people, animals, and materials away from uninfected birds; cleaning, to remove most of the contaminating organic matter; and disinfection, to decrease microbial load (De Benedictis et al. 2007; Wanaratana et al. 2010). Many technical recommendations on biosecurity practices have been issued for large(Newell et al. 2011) and small-scale producers (Negro-Calduch et al. 2013). According to the production scale and level of biosecurity measurements, Egyptian poultry production systems are classified into four sectors. Sector 1 consists of integrated broiler and breeder farms that have typically implemented standard operating procedures for biosecurity. Sector 2 
encompasses commercial poultry production systems with moderate to high biosecurity, birds or products usually marketed commercially, and strict prevention of contact with other poultry or wildlife. Poultry in sectors 1 and 2 in Egypt are reared in modern, high-standard biosecurity buildings equipped with air filtration systems, pretreated feeding systems, clear protocols for cleaning and disinfection, and strict entrance policies. Overall, farms in these sectors have been less affected by A(H5) infection (Abdelwhab and Hafez 2011). Sector 3 covers small commercial poultry production systems with low to no biosecurity and represents the major element for poultry production in Egypt. Most sector 3 farms are located near to or even within villages, are close to each other, and are the main source of live poultry for LBMs. Sector 4 consists of backyard production with no or minimal biosecurity, and birds or products are consumed locally or sold at LBMs (Negro-Calduch et al. 2013). Sectors 3 and 4 are the riskiest factors for virus evolution and transmission to humans.

Most poultry trade in Egypt depends on retail LBMs and street hawkers, which has been a major hurdle for $\mathrm{A}(\mathrm{H} 5)$ control. Because of the limited number of abattoirs (309 units in 2015) and the traditional Egyptian cultural preference for selling freshly slaughtered birds, LBMs are widespread in all rural and urban regions of Egypt. Different poultry species, including livecaptured wild birds, are housed together in these environments, sometimes in the same cage, where they stay for several days. Stray pets have free access and direct contact with waste and wastewater generated during slaughter, and cleaning runoff enters the main sewage system without treatment.

Different approaches to enforce biosecurity measures and reform practices in poultry farms are urgently needed and have been planned by the Egyptian government in cooperation with the Food and Agriculture Organization (Abdelwhab and Hafez 2011).

\section{Elimination of Infected Poultry}

During the first wave of $\mathrm{A}(\mathrm{H} 5 \mathrm{~N} 1)$ virus infection in Egypt, depopulation of affected flocks (within $3 \mathrm{~km}$ of the initial outbreak), quarantine and movement controls on poultry (within a $7-\mathrm{km}$ radius of the outbreak location) were implemented. Veterinary authorities provided partial compensation for affected farms. Subsequently, the incidence of $\mathrm{A}(\mathrm{H} 5 \mathrm{~N} 1)$ outbreaks decreased, although it is unclear whether that was the effect of rigorous culling strategies, administering inactivated vaccines, or a combination thereof. The estimated compensation during the first wave of $\mathrm{H} 5 \mathrm{~N} 1$ introduction in Egypt was \$29,375,000. After 2008, many farmers and breeders stopped reporting the presence of bird mortality within their flocks, especially after compensation was stopped and social stigma increased and due to other social aspects. It became almost impossible to control the virus under these circumstances.

Education and awareness are essential components of elimination strategies. Providing information about the virus and its effect to employees in poultry production helps provide justification and lower resistance for depopulation efforts. In Egypt, education and awareness programs in rural communities have been suggested but unfortunately not implemented (Ismail and Ahmed 2010).

\section{Active Surveillance}

An important component of AIV control is to implement active surveillance programs. Such programs not only provide an early alert for the incursion of emerging viruses but also allow monitoring the evolution and prevalence of endemic viruses, which can inform other control measures. Several surveillance studies on AIVs have been conducted in Egypt (Rabinowitz et al. 2012; Soliman et al. 2012; Afifi et al. 2013; Kayali et al. 2014) despite challenges in maintaining them. Inadequate financial and overall support from the state poses constant problems for surveillance activities in Egypt, with some governorates being very underrepresented. Although surveillance activities are one of the hardest aspects of control programs to maintain under resource constraints, their value cannot be underestimated. 
R. El-Shesheny et al.

\section{CONCLUDING REMARKS}

There are substantial challenges to the successful control of $\mathrm{A}(\mathrm{H} 5)$ viruses in Egypt and other endemically infected countries. Maintaining control strategies after the initial introduction of AIV into a country is daunting, and even more so after 13 years of continued virus circulation. Egypt is one of the countries hardest hit by $\mathrm{A}(\mathrm{H} 5)$ viruses, and there is no obvious end in sight. Although the frequency of human infections reported from Egypt has reduced with the introduction of clade 2.3.4.4 viruses, stasis is an unlikely long-term outcome. Vaccination must remain a central component of $\mathrm{A}(\mathrm{H} 5)$ control in Egypt, but by using a more concerted, controlled, and regulated approach than what has been done to date. Without doubt, viruses will continue to evolve in Egypt, and the threat of new introductions from Asia will remain. However, there is uncertainty about the future impact of virus evolution and introductions and in how to best use the limited existing control resources. Egypt must continue to leverage internal and external opportunities and partnerships to continue monitoring of and research into AIV and associated control measures.

\section{ACKNOWLEDGMENTS}

The authors thank Vani Shanker for critical review of this manuscript. The work was supported by the National Institute of Allergy and Infectious Diseases, National Institutes of Health (CEIRS Contract No. HHSN266200700005C).

This article has been made freely available online courtesy of TAUNS Laboratories.

\section{REFERENCES}

Abdel-Moneim AS, Abdel-Ghany AE, Shany SAS. 2010 Isolation and characterization of highly pathogenic avian influenza virus subtype $\mathrm{H} 5 \mathrm{~N} 1$ from donkeys. J Biomed Sci 17: 25. doi:10.1186/1423-0127-17-25

Abdelwhab EM, Hafez HM. 2011. An overview of the epidemic of highly pathogenic $\mathrm{H} 5 \mathrm{~N} 1$ avian influenza virus in Egypt: epidemiology and control challenges. Epidemiol Infect 139: 647-657. doi:10.1017/S0950268810003122

Abdelwhab el SM, Erfan AM, Grund C, Ziller M, Arafa AS, Beer M, Aly MM, Hafez HM, Harder TC. 2010. Simultaneous detection and differentiation by multiplex real time
RT-PCR of highly pathogenic avian influenza subtype H5N1 classic (clade 2.2.1 proper) and escape mutant (clade 2.2.1 variant) lineages in Egypt. Virol J 7: 260. doi:10.1186/1743-422X-7-260

Abdelwhab EM, Arafa AS, Stech J, Grund C, Stech O, Graeber-Gerberding M, Beer M, Hassan MK, Aly MM, Harder TC, et al. 2012a. Diversifying evolution of highly pathogenic H5N1 avian influenza virus in Egypt from 2006 to 2011. Virus Genes 45: 14-23. doi:10.1007/ s11262-012-0758-1

Abdelwhab EM, Grund C, Aly MM, Beer M, Harder TC, Hafez HM. 2012b. Influence of maternal immunity on vaccine efficacy and susceptibility of one day old chicks against Egyptian highly pathogenic avian influenza H5N1. Vet Microbiol 155: 13-20. doi:10.1016/j.vetmic .2011 .08 .004

Abdelwhab EM, Hassan MK, Abdel-Moneim AS, Naguib MM, Mostafa A, Hussein ITM, Arafa A, Erfan AM, Kilany WH, Agour MG, et al. 2016. Introduction and enzootic of A/H5N1 in Egypt: virus evolution, pathogenicity and vaccine efficacy ten years on. Infect Genet Evol 40: 80 90. doi:10.1016/j.meegid.2016.02.023

Abdelwhab EM, Veits J, Mettenleiter TC. 2017. Biological fitness and natural selection of amantadine resistant variants of avian influenza H5N1 viruses. Virus Res 228: 109-113. doi:10.1016/j.virusres.2016.11.032

Afifi MA, El-Kady MF, Zoelfakar SA, Abdel-Moneim AS. 2013. Serological surveillance reveals widespread influenza A H7 and H9 subtypes among chicken flocks in Egypt. Trop Anim Health Prod 45: 687-690. doi:10.1007/ s11250-012-0243-9

Alexander DJ. 2000. A review of avian influenza in different bird species. Vet Microbiol 74: 3-13. doi:10.1016/S03781135(00)00160-7

Aly MM, Arafa A, Hassan MK. 2008. Epidemiological findings of outbreaks of disease caused by highly pathogenic H5N1 avian influenza virus in poultry in Egypt during 2006. Avian Dis 52: 269-277. doi:10.1637/8166-103007Reg.1

Arafa AS, Naguib MM, Luttermann C, Selim AA, Kilany WH, Hagag N, Samy A, Abdelhalim A, Hassan MK, Abdelwhab EM, et al. 2015. Emergence of a novel cluster of influenza $\mathrm{A}(\mathrm{H} 5 \mathrm{~N} 1)$ virus clade 2.2.1.2 with putative human health impact in Egypt, 2014/15. Euro Surveill 20: 2-8. doi:10.2807/1560-7917.ES2015.20.13.21085

Arafa AS, Yamada S, Imai M, Watanabe T, Yamayoshi S, Iwatsuki-Horimoto K, Kiso M, Sakai-Tagawa Y, Ito M, Imamura T, et al. 2016. Risk assessment of recent Egyptian H5N1 influenza viruses. Sci Rep 6: 38388. doi:10 $.1038 /$ srep38388

Arai Y, Ibrahim MS, Elgendy EM, Daidoji T, Ono T, Suzuki Y, Nakaya T, Matsumoto K, Watanabe Y. 2019. Genetic compatibility of reassortants between avian $\mathrm{H} 5 \mathrm{~N} 1$ and H9N2 influenza viruses with higher pathogenicity in mammals. J Virol 93: e01969-e01918.

Balish AL, Davis CT, Saad MD, El-Sayed N, Esmat H, Tjaden JA, Earhart KC, Ahmed LE, Abd El-Halem M, Ali AH, et al. 2010. Antigenic and genetic diversity of highly pathogenic avian influenza A (H5N1) viruses isolated in Egypt. Avian Dis 54: 329-334. doi:10.1637/8903-042909-Reg.1

Beerens N, Heutink R, Bergervoet SA, Harders F, Bossers A, Koch G. 2017. Multiple reassorted viruses as cause of 
highly pathogenic avian influenza $\mathrm{A}(\mathrm{H} 5 \mathrm{~N} 8)$ virus epidemic, the Netherlands, 2016. Emerg Infect Dis 23: 1974-1981. doi:10.3201/eid2312.171062

Bertran K, Balzli C, Kwon YK, Tumpey TM, Clark A, Swayne DE. 2017. Airborne transmission of highly pathogenic influenza virus during processing of infected poultry. Emerg Infect Dis 23: 1806-1814. doi:10.3201/eid2311 .170672

Cattoli G, Fusaro A, Monne I, Coven F, Joannis T, El-Hamid HS, Hussein AA, Cornelius C, Amarin NM, Mancin M, et al. 2011. Evidence for differing evolutionary dynamics of $\mathrm{A} / \mathrm{H} 5 \mathrm{~N} 1$ viruses among countries applying or not applying avian influenza vaccination in poultry. Vaccine 29: 9368-9375. doi:10.1016/j.vaccine.2011.09.127

Chen LM, Blixt O, Stevens J, Lipatov AS, Davis CT, Collins BE, Cox NJ, Paulson JC, Donis RO. 2012. In vitro evolution of H5N1 avian influenza virus toward human-type receptor specificity. Virology 422: 105-113. doi:10.1016/j virol.2011.10.006

De Benedictis P, Beato MS, Capua I. 2007. Inactivation of avian influenza viruses by chemical agents and physical conditions: a review. Zoonoses Public Health 54: 51-68. doi:10.1111/j.1863-2378.2007.01029.x

Dinh PN, Long HT, Tien NT, Hien NT, Mai le TQ, Phong le H, Tuan le V, Van Tan H, Nguyen NB, Van Tu P, et al. 2006. Risk factors for human infection with avian influenza A H5N1, Vietnam, 2004. Emerg Infect Dis 12: 18411847. doi:10.3201/eid1212.060829

Earhart KC, Elsayed NM, Saad MD, Gubareva LV, Nayel A, Deyde VM, Abdelsattar A, Abdelghani AS, Boynton BR, Mansour MM, et al. 2009. Oseltamivir resistance mutation N294S in human influenza A(H5N1) virus in Egypt. J Infect Public Health 2: 74-80. doi:10.1016/j.jiph.2009.04 .004

Eladl AH, Hamed HR, Khalil MR. 2014. Consequence of cryptosporidiosis on the immune response of vaccinated broiler chickens against Newcastle disease and/or avian influenza. Veterinary Res Comms 38: 237-247. doi:10 1007/s11259-014-9610-5

ElMasry I, Elshiekh H, Abdlenabi A, Saad A, Arafa A, Fasina FO, Lubroth J, Jobre YM. 2017. Avian Influenza H5N1 surveillance and its dynamics in poultry in live bird markets, Egypt. Egypt. Trans Emerg Dis 64: 805-814. doi:10 $.1111 /$ tbed.12440

El-Shesheny R, Kayali G, Kandeil A, Cai Z, Barakat AB, Ghanim H, Ali MA. 2012. Antigenic diversity and cross-reactivity of avian influenza H5N1 viruses in Egypt between 2006 and 2011. J Gen Virol 93: 2564-2574. doi:10 .1099/vir.0.043299-0

El-Shesheny R, Kandeil A, Bagato O, Maatouq AM, Moatasim Y, Rubrum A, Song MS, Webby RJ, Ali MA, Kayali G. 2014. Molecular characterization of avian influenza $\mathrm{H} 5 \mathrm{~N} 1$ virus in Egypt and the emergence of a novel endemic subclade. J Gen Virol 95: 1444-1463. doi:10.1099/ vir.0.063495-0

El-Shesheny R, Bagato O, Kandeil A, Mostafa A, Mahmoud SH, Hassanneen HM, Webby RJ, Ali MA, Kayali G. 2016. Re-emergence of amantadine-resistant variants among highly pathogenic avian influenza H5N1 viruses in Egypt. Infect Genet Evol 46: 102-109. doi:10.1016/j.meegid.2016 .10 .022
El-Zoghby EF, Arafa AS, Hassan MK, Aly MM, Selim A, Kilany WH, Selim U, Nasef S, Aggor MG, Abdelwhab $\mathrm{EM}$, et al. 2012a. Isolation of H9N2 avian influenza virus from bobwhite quail (Colinus virginianus) in Egypt. Arch Virol 157: 1167-1172. doi:10.1007/s00705-012-1269-z

El-Zoghby EF, Arafa AS, Kilany WH, Aly MM, Abdelwhab EM, Hafez HM. 2012b. Isolation of avian influenza H5N1 virus from vaccinated commercial layer flock in Egypt. Virology J 9: 294. doi:10.1186/1743-422X-9-294

El-Zoghby EF, Aly MM, Nasef SA, Hassan MK, Arafa AS, Selim AA, Kholousy SG, Kilany WH, Safwat M, Abdelwhab EM, et al. 2013. Surveillance on A/H5N1 virus in domestic poultry and wild birds in Egypt. Virology J 10: 203. doi:10.1186/1743-422X-10-203

EMPRES. 2019. Emergency Prevention System Global Animal Disease Information System (EMPRES i). Food and Agriculture Organization of the United Nations.

Fusaro A, Monne I, Mulatti P, Zecchin B, Bonfanti L, Ormelli S, Milani A, Cecchettin K, Lemey P, Moreno A, et al. 2017. Genetic diversity of highly pathogenic avian influenza A(H5N8/H5N5) viruses in Italy, 2016-17. Emerg Infect Dis 23: 1543-1547. doi:10.3201/eid2309.170539

Gomaa MR, Kayed AS, Elabd MA, Zeid DA, Zaki SA, El Rifay AS, Sherif LS, McKenzie PP, Webster RG, Webby RJ, et al. 2015. Avian influenza $A(H 5 N 1)$ and $A(H 9 N 2)$ seroprevalence and risk factors for infection among Egyptians: a prospective, controlled seroepidemiological study. J Infect Dis 211: 1399-1407. doi:10.1093/infdis/jiu529

Guan Y, Poon LLM, Cheung CY, Ellis TM, Lim W, Lipatov AS, Chan KH, Sturm-Ramirez KM, Cheung CL, Leung YHC, et al. 2004. H5N1 influenza: a protean pandemic threat. Proc Natl Acad Sci 101: 8156-8161. doi:10.1073/ pnas.0402443101

Hafez MH, Arafa A, Abdelwhab EM, Selim A, Khoulosy SG, Hassan MK, Aly MM. 2010. Avian influenza H5N1 virus infections in vaccinated commercial and backyard poultry in Egypt. Poultry Sci 89: 1609-1613. doi:10.3382/ps .2010-00708

Hagag NM, Erfan AM, El-Husseiny M, Shalaby AG, Saif MA, Tawakol MM, Nour AA, Selim AA, Arafa AS, Hassan $\mathrm{MK}$, et al. 2019. Isolation of a novel reassortant highly pathogenic avian influenza (H5N2) virus in Egypt. Viruses 11: pii: E565. doi:10.3390/v11060565

Harder T, Maurer-Stroh S, Pohlmann A, Starick E, HörethBontgen D, Albrecht K, Pannwitz G, Teifke J, Gunalan V, Lee RT, et al. 2015. Influenza A(H5N8) virus similar to strain in Korea causing highly pathogenic avian influenza in Germany. Emerg Infect Dis 21: 860-863. doi:10.3201/ eid2105.141897

Hassan KE, El-Kady MF, El-Sawah AAA, Luttermann C, Parvin R, Shany S, Beer M, Harder T. 2019. Respiratory disease due to mixed viral infections in poultry flocks in Egypt between 2017 and 2018: upsurge of highly pathogenic avian influenza virus subtype H5N8 since 2018 . Transbound Emerg Dis doi: 10.1111/tbed.13281.

Herfst S, Schrauwen EJ, Linster M, Chutinimitkul S, de Wit E, Munster VJ, Sorrell EM, Bestebroer TM, Burke DF, Smith DJ, et al. 2012. Airborne transmission of influenza A/H5N1 virus between ferrets. Science 336: 1534-1541. doi:10.1126/science.1213362

Imai M, Watanabe T, Hatta M, Das SC, Ozawa M, Shinya K, Zhong G, Hanson A, Katsura H, Watanabe S, et al. 2012. 
R. El-Shesheny et al.

Experimental adaptation of an influenza H5 HA confers respiratory droplet transmission to a reassortant $\mathrm{H} 5 \mathrm{HA} /$ H1N1 virus in ferrets. Nature 486: 420-428. doi:10.1038/ nature10831

Ismail NA, Ahmed HA. 2010. Knowledge, attitudes and practices related to avian influenza among a rural community in Egypt. J Egypt Public Health Assoc 85: 73-96.

Kandeel A, Manoncourt S, Abd el Kareem E, Mohamed Ahmed AN, El-Refaie S, Essmat H, Tjaden J, de Mattos CC, Earhart KC, Marfin AA, et al. 2010. Zoonotic transmission of avian influenza virus (H5N1), Egypt, 20062009. Emerg Infect Dis 16: 1101-1107. doi:10.3201/ eid1607.091695

Kandeil A, El-Shesheny R, Maatouq AM, Moatasim Y, Shehata MM, Bagato O, Rubrum A, Shanmuganatham K, Webby RJ, Ali MA, et al. 2014. Genetic and antigenic evolution of H9N2 avian influenza viruses circulating in Egypt between 2011 and 2013. Arch Virol 159: 28612876. doi:10.1007/s00705-014-2118-Z

Kandeil A, Kayed A, Moatasim Y, Webby RJ, McKenzie PP, Kayali G, Ali MA. 2017. Genetic characterization of highly pathogenic avian influenza A H5N8 viruses isolated from wild birds in Egypt. J Gen Virol 98: 1573-1586. doi:10.1099/jgv.0.000847

Kayali G, El-Shesheny R, Kutkat MA, Kandeil AM, Mostafa A, Ducatez MF, McKenzie PP, Govorkova EA, Nasraa MH, Webster RG, et al. 2011a. Continuing threat of influenza (H5N1) virus circulation in Egypt. Emerg Infect Dis 17: 2306-2308. doi:10.3201/eid1712.110683

Kayali G, Webby RJ, Ducatez MF, El Shesheny RA, Kandeil AM, Govorkova EA, Mostafa A, Ali MA. 2011b. The epidemiological and molecular aspects of influenza H5N1 viruses at the human-animal interface in Egypt. PLoS ONE 6: e17730. doi:10.1371/journal.pone.0017730

Kayali G, Kandeil A, El-Shesheny R, Kayed AS, Gomaa MR, Kutkat MA, Debeauchamp J, McKenzie PP, Webster RG, Webby RJ, et al. 2013. Do commercial avian influenza H5 vaccines induce cross-reactive antibodies against contemporary H5N1 viruses in Egypt? Poult Sci 92: 114-118. doi:10.3382/ps.2012-02637

Kayali G, Kandeil A, El-Shesheny R, Kayed AS, Gomaa MM, Maatouq AM, Shehata MM, Moatasim Y, Bagato O, Cai $\mathrm{Z}$, et al. 2014. Active surveillance for avian influenza virus, Egypt, 2010-2012. Emerg Infect Dis 20: 542-551. doi:10 $.3201 /$ eid2004.131295

Kayali G, Kandeil A, El-Shesheny R, Kayed AS, Maatouq AM, Cai Z, McKenzie PP, Webby RJ, El Refaey S, Kandeel A, et al. 2016. Avian influenza A(H5N1) virus in Egypt. Emerg Infect Dis 22: 379-388. doi:10.3201/eid2203 .150593

Kayed AS, Kandeil A, El Shesheny R, Ali MA, Kayali G. 2016. Active surveillance of avian influenza viruses in Egyptian poultry, 2015. East Mediterr Health J 22: 557-561. doi:10 $.26719 / 2016.22 .7 .553$

Kayed AS, Kandeil A, Gomaa MR, El-Shesheny R, Mahmoud S, Hegazi N, Fayez M, Sheta B, McKenzie PP, Webby RJ, et al. 2019. Surveillance for avian influenza viruses in wild birds at live bird markets, Egypt, 2014-2016. Influenza Other Respir Viruses 13: 407-414. doi:10.1111/irv .12634

Kilany WH, Abdelwhab EM, Arafa AS, Selim A, Safwat M, Nawar AA, Erfan AM, Hassan MK, Aly MM, Hafez HM.
2011. Protective efficacy of H5 inactivated vaccines in meat turkey poults after challenge with Egyptian variant highly pathogenic avian influenza H5N1 virus. Vet Microbiol 150: 28-34. doi:10.1016/j.vetmic.2010.12.016

Kim JK, Kayali G, Walker D, Forrest HL, Ellebedy AH, Griffin YS, Rubrum A, Bahgat MM, Kutkat MA, Ali MA, et al. 2010. Puzzling inefficiency of H5N1 influenza vaccines in Egyptian poultry. Proc Natl Acad Sci 107: 11044-11049. doi:10.1073/pnas.1006419107

Kleyheeg E, Slaterus R, Bodewes R, Rijks JM, Spierenburg MAH, Beerens N, Kelder L, Poen MJ, Stegeman JA, Fouchier RAM, et al. 2017. Deaths among wild birds during highly pathogenic avian influenza $\mathrm{A}(\mathrm{H} 5 \mathrm{~N} 8)$ virus outbreak, the Netherlands. Emerg Infect Dis 23: 20502054. doi:10.3201/eid2312.171086

Lai S, Qin Y, Cowling BJ, Ren X, Wardrop NA, Gilbert M, Tsang TK, Wu P, Feng L, Jiang H, et al. 2016. Global epidemiology of avian influenza A H5N1 virus infection in humans, 1997-2015: a systematic review of individual case data. Lancet Infect Dis 16: e108-e118. doi:10.1016/ S1473-3099(16)00153-5

Lee DH, Bertran K, Kwon JH, Swayne DE. 2017. Evolution, global spread, and pathogenicity of highly pathogenic avian influenza H5Nx clade 2.3.4.4. J Vet Sci 18: 269280. doi:10.4142/jvs.2017.18.S1.269

Marinova-Petkova A, Shanmuganatham K, Feeroz MM, Jones-Engel L, Hasan MK, Akhtar S, Turner J, Walker D, Seiler P, Franks J, et al. 2016. The continuing evolution of $\mathrm{H} 5 \mathrm{~N} 1$ and $\mathrm{H} 9 \mathrm{~N} 2$ influenza viruses in Bangladesh between 2013 and 2014. Avian Dis 60: 108-117. doi:10 .1637/11136-050815-Reg

Moatasim Y, Kandeil A, Mostafa A, Elghaffar SKA, El Shesheny R, Elwahy AHM, Ali MA. 2017. Single gene reassortment of highly pathogenic avian influenza A H5N1 in the low pathogenic H9N2 backbone and its impact on pathogenicity and infectivity of novel reassortant viruses. Arch Virol 162: 2959-2969. doi:10.1007/s00705-0173434-x

Monne I, Yamage M, Dauphin G, Claes F, Ahmed G, Giasuddin M, Salviato A, Ormelli S, Bonfante F, Schivo A, et al. 2013. Reassortant avian influenza A(H5N1) viruses with H9N2-PB1 gene in poultry, Bangladesh. Emerg Infect Dis 19: 1630-1634. doi:10.3201/eid1910.130534

Naguib MM, Arafa ASA, El-Kady MF, Selim AA, Gunalan V, Maurer-Stroh S, Goller KV, Hassan MK, Beer M, Abdelwhab EM, et al. 2015. Evolutionary trajectories and diagnostic challenges of potentially zoonotic avian influenza viruses $\mathrm{H} 5 \mathrm{~N} 1$ and $\mathrm{H} 9 \mathrm{~N} 2$ co-circulating in Egypt: infection, genetics and evolution. J Mol Epidemiol Evol Gen Infect Dis 34: 278-291. doi:10.1016/j.meegid.2015.06.004

Naguib MM, Ulrich R, Kasbohm E, Eng CLP, Hoffmann D, Grund C, Beer M, Harder TC. 2017. Natural reassortants of potentially zoonotic avian influenza viruses $\mathrm{H} 5 \mathrm{~N} 1$ and H9N2 from Egypt display distinct pathogenic phenotypes in experimentally infected chickens and ferrets. J Virol 91: e01300-17. doi:10.1128/JVI.01300-17

Negro-Calduch E, Elfadaly S, Tibbo M, Ankers P, Bailey E. 2013. Assessment of biosecurity practices of small-scale broiler producers in central Egypt. Prev Vet Med 110: 253-262. doi:10.1016/j.prevetmed.2012.11.014

Newell DG, Elvers KT, Dopfer D, Hansson I, Jones P, James S, Gittins J, Stern NJ, Davies R, Connerton I, et al. 2011. 
Biosecurity-based interventions and strategies to reduce Campylobacter spp on poultry farms. Appl Environ Microbiol 77: 8605-8614. doi:10.1128/AEM.01090-10

Peyre M, Samaha H, Makonnen YJ, Saad A, Abd-Elnabi A, Galal S, Ettel T, Dauphin G, Lubroth J, Roger F, et al. 2009. Avian influenza vaccination in Egypt: limitations of the current strategy. J Mol Genet Med 3: 198-204.

Pfeiffer J, Suarez DL, Sarmento L, To TL, Nguyen T, PantinJackwood MJ. 2010. Efficacy of commercial vaccines in protecting chickens and ducks against $\mathrm{H} 5 \mathrm{~N} 1$ highly pathogenic avian influenza viruses from Vietnam. Avian Dis 54: 262-271. doi:10.1637/8715-031909-Reg.1

Pohlmann A, Starick E, Harder T, Grund C, Höper D, Globig A, Staubach C, Dietze K, Strebelow G, Ulrich RG, et al. 2017. Outbreaks among wild birds and domestic poultry caused by reassorted influenza $\mathrm{A}(\mathrm{H} 5 \mathrm{~N} 8)$ clade 2.3.4.4 viruses, Germany, 2016. Emerg Infect Dis 23: 633-636. doi:10.3201/eid2304.161949

Rabinowitz PM, Galusha D, Vegso S, Michalove J, Rinne S, Scotch M, Kane M. 2012. Comparison of human and animal surveillance data for H5N1 influenza A in Egypt 2006-2011. PLoS ONE 7: e43851. doi:10.1371/journal .pone.0043851

Refaey S, Azziz-Baumgartner E, Amin MM, Fahim M, Roguski K, Elaziz HA, Iuliano AD, Salah N, Uyeki TM, Lindstrom S, et al. 2015. Increased number of human cases of influenza virus $\mathrm{A}(\mathrm{H} 5 \mathrm{~N} 1)$ infection, Egypt, 2014-15. Emerg Infect Dis 21: 2171-2173. doi:10.3201/ eid2112.150885

Saad MD, Ahmed LS, Gamal-Eldein MA, Fouda MK, Khalil F, Yingst SL, Parker MA, Montevillel MR. 2007. Possible avian influenza (H5N1) from migratory bird, Egypt. Emerg Infect Dis 13: 1120-1121. doi:10.3201/eid1307 .061222

Salaheldin AH, El-Hamid A, Elbestawy AR, Veits J, Hafez HM, Mettenleiter TC, Abdelwhab EM. 2018a. Multiple introductions of influenza $\mathrm{A}(\mathrm{H} 5 \mathrm{~N} 8)$ virus into poultry, Egypt, 2017. Emerg Infect Dis 24: 943-946. doi:10.3201/ eid2405.171935

Salaheldin AH, Kasbohm E, El-Naggar H, Ulrich R, Scheibner D, Gischke M, Hassan MK, Arafa AA, Hassan WM, Abd El-Hamid HS, et al. 2018b. Potential biological and climatic factors that influence the incidence and persistence of highly pathogenic $\mathrm{H} 5 \mathrm{~N} 1$ avian influenza virus in Egypt. Front Microbiol 9: 528. doi:10.3389/fmicb.2018 .00528

Samaha HA, Ibrahim MS, Ayoub M, Shaaban SI. 2015. Seroepidemiology of avian influenza viruses $\mathrm{H} 5$ and $\mathrm{H} 9$ in Beheira Governorate. Alexandria J Vet Sci 44: 86-92. doi:10.5455/ajvs.161061

Samir M, Hamed M, Abdallah F, Kinh Nguyen V, Hernandez-Vargas EA, Seehusen F, Baumgärtner W, Hussein A Ali AAH, Pessler F. 2018. An Egyptian HPAI H5N1 isolate from clade 2.2.1.2 is highly pathogenic in an experimentally infected domestic duck breed (Sudani duck). Transbound Emerg Dis 65: 859-873. doi:10.1111/tbed .12816
Schmier S, Mostafa A, Haarmann T, Bannert N, Ziebuhr J, Veljkovic V, Dietrich U, Pleschka S. 2015. In silico prediction and experimental confirmation of HA residues conferring enhanced human receptor specificity of H5N1 influenza A viruses. Sci Rep 5: 11434. doi:10 $.1038 /$ srep 11434

Scoizec A, Niqueux E, Thomas R, Daniel P, Schmitz A, Le Bouquin S. 2018. Airborne detection of H5N8 highly pathogenic avian influenza virus genome in poultry farms, France. Front Vet Sci 5: 15. doi:10.3389/fvets .2018 .00015

Soliman A, Saad M, Elassal E, Amir E, Plathonoff C, Bahgat V, El-Badry M, Ahmed LS, Fouda M, Gamaleldin M, et al. 2012. Surveillance of avian influenza viruses in migratory birds in Egypt, 2003-09. J Wildl Dis 48: 669-675. doi:10 $.7589 / 0090-3558-48.3 .669$

Swayne DE. 2012. Impact of vaccines and vaccination on global control of avian influenza. Avian Dis 56: 818828. doi:10.1637/10183-041012-Review.1

Wanaratana S, Tantilertcharoen R, Sasipreeyajan J, Pakpinyo S. 2010. The inactivation of avian influenza virus subtype H5N1 isolated from chickens in Thailand by chemical and physical treatments. Vet Microbiol 140: 43-48. doi:10.1016/j.vetmic.2009.07.008

Watanabe Y, Ibrahim MS, Ellakany HF, Kawashita N, Mizuike R, Hiramatsu H, Sriwilaijaroen N, Takagi T, Suzuki Y, Ikuta K. 2011. Acquisition of human-type receptor binding specificity by new H5N1 influenza virus sublineages during their emergence in birds in Egypt. PLoS Pathog 7: e1002068. doi:10.1371/journal.ppat.1002068

Webster RG, Bean WJ, Gorman OT, Chambers TM, Kawaoka Y. 1992. Evolution and ecology of influenza A viruses. Microbiol Rev 56: 152-179.

WHO. 2019. WHO cumulative number of confirmed human cases for avian influenza $\mathrm{A}(\mathrm{H} 5 \mathrm{~N} 1)$ reported to WHO, 2003-2019. https://wwwwhoint/influenza/human animal_interface/2019._06_24_tableH5N1pdf?ua=1

Wu Y, Lin J, Yang S, Xie Y, Wang M, Chen X, Zhu Y, Luo L, Shi W. 2018. The molecular characteristics of avian influenza viruses (H9N2) derived from air samples in live poultry markets. Infect Genet Evol 60: 191-196. doi:10 $.1016 /$ j.meegid.2018.01.009

Yehia N, Naguib MM, Li R, Hagag N, El-Husseiny M, Mosaad Z, Nour A, Rabea N, Hasan WM, Hassan MK, et al. 2018. Multiple introductions of reassorted highly pathogenic avian influenza viruses ( $\mathrm{H} 5 \mathrm{~N} 8$ ) clade 2.3.4.4b causing outbreaks in wild birds and poultry in Egypt. Infect Genet Evol 58: 56-65. doi:10.1016/j.meegid.2017.12.011

Younan M, Poh MK, Elassal E, Davis T, Rivailler P, Balish AL, Simpson N, Jones J, Deyde V, Loughlin R, et al. 2013. Microevolution of highly pathogenic avian influenza A(H5N1) viruses isolated from humans, Egypt, 20072011. Emerg Infect Dis 19: 43-50. doi:10.3201/eid1901 .121080

Zhou L, Liao Q, Dong L, Huai Y, Bai T, Xiang N, Shu Y, Liu W, Wang S, Qin P, et al. 2009. Risk factors for human illness with avian influenza A (H5N1) virus infection in China. J Infect Dis 199: 1726-1734. doi:10.1086/599206 


\section{$\&_{\mathrm{CSH}}^{\infty} \&$ Cold Spring Harbor

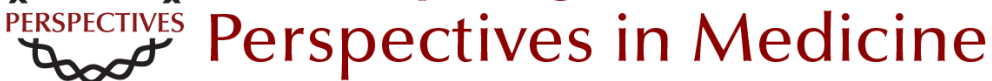

\section{H5 Influenza Viruses in Egypt}

Rabeh El-Shesheny, Ahmed Kandeil, Ahmed Mostafa, Mohamed A. Ali and Richard J. Webby

Cold Spring Harb Perspect Med 2021; doi: 10.1101/cshperspect.a038745 originally published online March 2, 2020

\section{Subject Collection Influenza: The Cutting Edge}

\section{Emerging HxNy Influenza A Viruses} William J. Liu, Yan Wu, Yuhai Bi, et al.

Equine Influenza

Thomas M. Chambers

\section{Human Influenza Epidemiology}

Sukhyun Ryu and Benjamin J. Cowling

Host Cell Factors That Interact with Influenza

Virus Ribonucleoproteins

Ecco Staller and Wendy S. Barclay

Induction and Evasion of Type-I Interferon

Responses during Influenza A Virus Infection

Raquel Muñoz-Moreno, Carles Martínez-Romero and Adolfo García-Sastre

Structure and Function of Influenza Polymerase Joanna M. Wandzik, Tomas Kouba and Stephen Cusack

H7N9 Influenza Virus in China Chengjun Li and Hualan Chen

\section{H5 Influenza Viruses in Egypt}

Rabeh El-Shesheny, Ahmed Kandeil, Ahmed Mostafa, et al.
Antivirals Targeting the Neuraminidase Larisa Gubareva and Teena Mohan

Accessory Gene Products of Influenza A Virus Rute M. Pinto, Samantha Lycett, Eleanor Gaunt, et al.

Influenza Immunization in the Context of

Preexisting Immunity Susanne L. Linderman, Ali H. Ellebedy, Carl Davis, et al.

Hemagglutinin Structure and Activities Steven J. Gamblin, Sébastien G. Vachieri, Xiaoli Xiong, et al.

Live Attenuated Cold-Adapted Influenza Vaccines Kanta Subbarao

Next-Generation Influenza Vaccines Masaru Kanekiyo and Barney S. Graham

Selective Genome Packaging Mechanisms of Influenza A Viruses

Takeshi Noda

Systems Biological Analysis of Immune Response to Influenza Vaccination Mario Cortese, Amy C. Sherman, Nadine G. Rouphael, et al.

For additional articles in this collection, see http://perspectivesinmedicine.cshlp.org/cgi/collection/ 